\title{
$\mathrm{AC}$ 모듈형 태양광 모듈 집적형 컨버터를 위한 소프트 스위칭 DC-DC 컨버터
}

윤선재 $^{1}$, 김영호 $^{2}$, 정용채 $^{3}$, 원 충연 $^{\dagger}$

\section{Soft Switching DC-DC Converter for AC Module Type PV Module Integrated Converter}

\author{
Sun-Jae Youn ${ }^{1}$, Young-Ho Kim², Yong-Chae Jung ${ }^{3}$, and Chung-Yuen $\mathrm{Won}^{\dagger}$
}

\begin{abstract}
In this paper, a soft switching DC-DC converter for AC module type photovoltaic (PV) module integrated converter is proposed. A push-pull converter is suitable for a low voltage PV AC module system because the step-up ratio of a high frequency transformer is high and the number of primary side switches is relatively small. However, the conventional push-pull converters do not have high efficiency because of high switching losses by hard switching and transformer losses (copper and iron losses) by high turns-ratio of the transformer. In the proposed converter, primary side switches are turned on at zero voltage switching (ZCS) condition and turned off at zero current switching (ZVS) condition through parallel resonance between secondary leakage inductance of the transformer and a resonant capacitor. Therefore the proposed push-pull converter decreases the switching loss using soft switching of the primary switches. Also, the turns-ratio of the transformer can be reduced by half using a voltage-doubler of secondary side. The theoretical analysis of the proposed converter is verified by simulation and experimental results.
\end{abstract}

Keywords: push-pull converter, soft-switching, current-fed, PV module integrated converter, AC module

\section{1. 서 론}

최근 환경 오염과 화석 연료 고갈의 심각한 문제 때 문에, 태양광은 신재생 에너지로써 각광받고 있다. 태양 광 발전 시스템을 위한 많은 종류의 인버터 회로와 관 련된 제어 기법이 연구되어지고 있다. 과거에는 많은 태 양광 모듈이 계통에 연계되는 중앙 집권형 인버터를 기 반으로 한 태양광 발전 시스템이 사용되었다. 태양광 모 듈의 직렬연결로 구성된 직렬연결은 고 전력 발전을 위 하여 직렬연결 다이오드를 통하여 병렬로 연결된다. 이 시스템은 태양광 모듈과 인버터 사이의 고전압 dc 모선

\footnotetext{
Paper number: TKPE-2013-18-3-7 ISSN: 1229-2214

† Corresponding author: woncy@.skku.edu, School of

Information and Communication Engineering, Sungkyunkwan University

Tel: +82-31-290-7115 Fax: +82-31-290-7179

${ }^{1}$ Samsung Electro-mechanics Co., Ltd.

${ }^{2}$ School of Information and Communication Engineering, Sungkyunkwan University

${ }^{3}$ Dept of Electronic Engineering, Namseoul University Manuscript received Nov. 9, 2012; accepted Feb. 12, 2013
}

(dc bus line)과 태양광 모듈 사이의 불균형 손실, 직렬 연결 다이오드에 의한 손실, 대용량 구성으로 인한 설계 의 복잡성과 같은 단점이 있다. 그래서 직렬 연결된 태 양광 모듈을 사용한 타입의 인버터가 개선된 방법이다. 직렬연결 다이오드에 의한 손실이 없고, 각 직렬연결 마 다 분리된 MPPT (Maximum Power Point Tracking)가 가능하다. 이는 중앙 집권형과 비교하여 전반적인 효율 을 늘릴 수 있다. 그러나 최근에, 각 태양광 모듈에 집 적된 MIC (Module Integrated Converter) 타입 인버터 가 각광받고 있다. 이 타입은 개별적인 MPPT를 이용하 여 태양광 모듈 사이의 불평형을 제거하였다. 그중 $\mathrm{AC}$ 모듈 타입은 개별 $\mathrm{MIC}$ 의 각 출력이 $\mathrm{AC}$ 계통으로 연결 되기 때문에 $\mathrm{AC}$ 케이블만 필요하다. 모듈 구조 때문에 시스템 확장이 쉽고, 부착 시 바로 사용(plug-and-play) 가능한 장치를 통하여 설치를 쉽게 하였다. $\mathrm{AC}$ 모듈 인 버터는 고효율, 비용 효과, 신뢰성을 가지기 때문에, 태 양광 발전 시스템을 위해 최선이라 할 수 있다 ${ }^{[1]-[3]}$.

본 논문에서는 $\mathrm{AC}$ 모듈 타입의 태양광 $\mathrm{MIC}$ 중 $\mathrm{DC}-\operatorname{link}$ 를 갖는 구조에서 $\mathrm{DC}-\mathrm{DC}$ 전력 변환 부의 새로 
운 토폴로지를 제안하였다.

본 논문은 다음과 같이 구성된다. 일반적인 푸쉬-풀 컨버터의 특징을 2장에서 다룬다. 제안된 소프트 스위칭 전류원형 푸쉬-풀 컨버터의 모델링과 구현은 3장에서 다루었다. 시뮬레이션 결과는 4장에서 다루었고, 실험 결과는 5장에서 다루었다. 결론은 6장에 주어져있다.

\section{2. 일반적인 푸쉬-풀 컨버터}

푸쉬-풀 컨버터는 적은 소자수, 간단함, 태양광 모듈 과 $\mathrm{AC}$ 계통간의 절연의 장점 때문에 태양광 $\mathrm{MIC}$ 에 활 용될 수 있다. Two-stage 구조 중 $\mathrm{PWM}(\mathrm{Pulse}$ Width Modulation) 인버터에서, DC-link 전압과 출력 전류가 제어 된다. 그래서, 커패시터의 전압은 $\mathrm{AC}$ 계통의 주파 수를 갖는 전압 리플의 영향을 적게 받는다. 따라서 컨 버터는 출력단에 $10 \sim 20 \mu \mathrm{F}$ 의 작은 디커플링(decoupling) 커패시터만이 필요하다.

변압기의 1 차 측에서, 일반적인 푸쉬-풀 컨버터는 전 압원을 사용한다. 그러나 이는 낮은 입력 전압과 높은 출력 전압 때문에 높은 승압비를 가져야 하는 $\mathrm{AC}$ 모듈 타입에 적합하지 않다. 그래서 푸쉬-풀 컨버터는 변압기 의 권선비를 줄일 수 있는 전류원을 사용한다. 부스트 인덕터에 의하여 변압기의 1 차 측 전압이 입력 전압보 다 크게 된다. 그 결과 권선비가 감소하여 변압기의 동 손 및 누설 성분이 저감된다. 이 장점들 때문에 신재생 에너지 시스템을 위하여 전류원 컨버터가 전압원 컨버 터 보다 적합하다 ${ }^{[4]-[5]}$.

변압기 2차 측에서, 기존의 푸쉬-풀 컨버터는 센터탭 방식과 풀브릿지 타입으로 구성된다. 센터탭 타입에서, 다이오드 양단의 전압 스트레스가 풀브릿지 타입에서의 스트레스 보다 높다. 그러므로 센터탭 타입은 변압기 2 차 측이 고전압을 갖는 토폴로지에 적합하지 않다. 풀브 릿지 타입에서 다이오드는 4개로 구성되기 때문에 전압 스트레스는 절반으로 감소할 수 있다. 그래서 풀브릿지 타입이 계통 연계형 태양광 $\mathrm{MIC}$ 에 더 적합하다 ${ }^{[6]}$.

기존의 푸쉬-풀 컨버터는 또한 고주파 스위칭 시에 하드 스위칭에 의한 스위칭 손실을 갖는다. 또한, 낮은 전압의 태양광 모듈을 고전압의 $\mathrm{AC}$ 계통에 연계하기 위하여 높은 권선비를 갖기 때문에 변압기에서 높은 손 실이 발생한다. 일반적인 푸쉬-풀 컨버터의 주요 회로는 Fig. 1에 나타나 있다.

이 문제점들을 해결하기 위하여, 스위칭 손실과 변압기 의 손실을 줄이기 위한 소프트 스위칭 전류원형 푸쉬-풀 컨버터가 제안되었다. 제안된 푸쉬-풀 컨버터는 부스트 인덕터, 두 개의 스위치, 고주파 변압기, 공진 커패시터, 배압회로로 구성된다. 변압기 2차 측 누설 인덕턴스와 공 진 커패시터 사이의 병렬 동진을 사용한 소프트 스위칭 으로 스위칭 손실을 저감할 수 있다. 또한 부스트인덕터 와 배압회로를 통하여 변압기의 손실을 저감할 수 있다.

\section{3. 제안하는 푸쉬-풀 컨버터}

\section{1 제안된 컨버터의 특징}

제안된 푸쉬-풀 컨버터의 주요 회로도는 그림 2와 같 다. 회로는 부스트 인덕터 Lbst, 스위치 $\left(S_{1}, S_{2}\right)$, 고주파 변압기, 배압 회로로 구성되어 있다 ${ }^{[7]-[10]}$. 소프트 스위칭 에 사용되는 LC 병렬 공진 회로는 변압기 2차 측 누설 인덕턴스 $L_{k}$ 와 공진 커패시터 $C_{r}$ 로 구성되어 있다. 1차 측 스위치는 $\mathrm{ZCS}$ 조건에서 턴-온 되고 $\mathrm{ZVS}$ 조건에서 턴-오프 된다. 배압회로의 다이오드 $\left(D_{1}, D_{2}\right)$ 또한 ZCS 조건에서 턴-오프 된다. Lbst는 변압기 1차 측 전압 ( $V T 1$, $V T 2)$ 를 입력 전압 보다 높게 해주며, 배압 회로는 변압기 2 차 측 전압 $V T 3$ 를 출력 전압의 절반으로 만들어 준다. 따라서 Lbst와 배압회로를 통하여 변압기의 권선비를 줄 일 수 있고, 변압기의 크기 및 손실 또한 줄일 수 있다.

$V T 1, V T 2$ 는 입력 전압 Vin과 Lbst의 전압 VLbst의 합이고, 배압회로의 전압 $\left(V_{o 1}, V_{o 2}\right)$ 는 $0.5 V_{o}$ 와 같으며, $V T 3$ 은 배 압 회로의 전압과 누설 인덕턴스 전압 $V L k$ 의 합이다. 그 리고 병렬로 연결된 $C_{r}$ 의 전압 $V_{C r}$ 은 구형파 $\left(-0.5 V_{0}\right.$, $\left.0.5 V_{o}\right)$ 형태를 갖는다. 이에 관련된 수식은 식 (1), (2), (3)과 같다.

$$
\begin{gathered}
v_{T_{3}}=\frac{1}{2} V_{o}-v_{L_{k}}=v_{C r}+v_{L_{k}} \\
v_{T_{1}}=\frac{1}{n} v_{T_{3}}=\frac{1}{n}\left(v_{C r}+v_{L_{k}}\right) \\
v_{i n}+v_{L_{b s t}}=\frac{1}{n}\left(v_{C r}+v_{L_{k}}\right)
\end{gathered}
$$

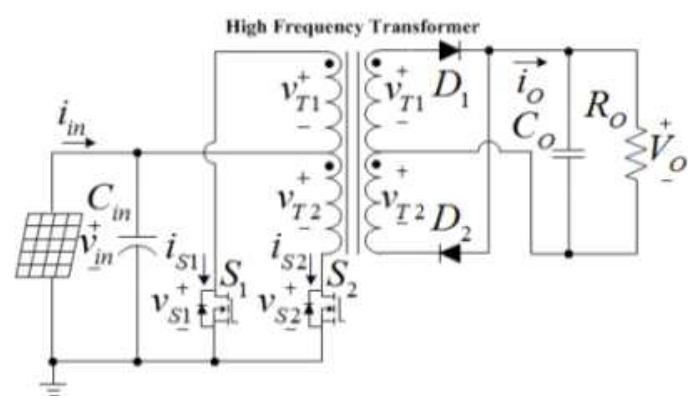

Fig. 1 Main circuit of the conventional push-pull converter

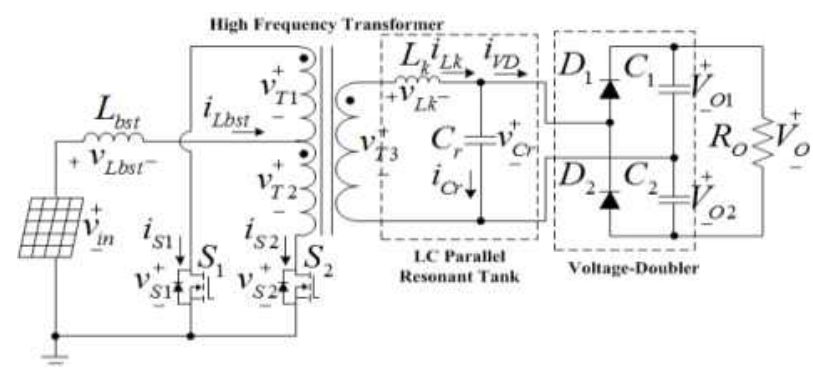

Fig. 2 Main circuit of the proposed push-pull converter 
소프트 스위칭과 $\mathrm{MPPT}$ 수행을 위해서 시비율 $D$ 와 스위칭 주파수 $f_{S W}$ 는 일사량에 따라 함께 가변되어야 한 다. $D$ 는 $f_{S W}$ 가 변함에 따라 자연스럽게 변하게 된다.

변압기의 1,2 차 측 권선 길이에 따라 결합도가 변하 며, $L k$ 는 조절되도록 하였다. 높은 1 차 측 전류 때문에 사각 Litz 와이어가 사용되었다.

\section{2 제안된 컨버터의 동작}

제안된 컨버터의 주요 파형은 Fig. 3에 나타나있다. 시간 $t_{0}$ 에서 $t 10$ 까지 스위칭 주기 동안 10 개의 구간으로 나뉘며, 5개 모드가 반복된다. 제안된 컨버터의 전류 흐 름에 따른 동작모드는 Fig. 4에 나타나있다 ${ }^{[11]-[12]}$.

\section{모드 $1\left(t_{0} \sim t_{1}\right)$ :}

$S_{1}$ 이 턴-온 되어 전류가 흐르기 시작한다. 공진 회로 에서 공진 전류의 흐름의 방향이 바뀐다. $L_{k}$ 의 전류 $i L k$ 는 공진 곡선을 그리며 감소하고, 그 결과 $S_{1}$ 의 전류 $i S 1$ 은 같은 모양으로 증가하여 $\mathrm{ZCS}$ 조건에서 턴-온 할 수 있으며 $S_{2}$ 의 전류 $i S_{2}$ 는 같은 모양으로 감소한다. $S_{2}$ 에 의하여 변압기 코어에 이미 형성되어 있던 자속은 턴온된 $S_{1}$ 에 의해 반대로 형성된 자속에 의해 상쇄된다. 따라서 자화 에너지는 변압기 2차 측으로 전달되지 못 하며, $L_{k}$ 의 에너지가 방출되어 $D_{1}$ 이 $Z \mathrm{VS}$ 조건에서 턴오프 된다. $i L b s t$ 와 $i L k$ 의 수식은 다음과 같다.

$$
\begin{aligned}
& i_{L_{\text {bst }}}(t)=I_{0} \cos \omega_{1} t+\frac{\left(V_{\text {in }}-V_{C_{1}}\right)}{Z_{1}} \sin \omega_{1} t \\
& i_{L_{k}}(t)=\frac{2 V_{o}-v_{C_{2}}\left(t_{0}\right)}{Z_{r}} \sin \omega_{r}(t)
\end{aligned}
$$

\section{모드 2(t1 t2) :}

공진 곡선을 그리며 $i s 1$ 은 증가하고 $i S 2$ 는 감소한다. 공 진 회로의 전류는 음의 전류가 되었다. 이 모드는 ${ }_{i S 2}$ 가 0이 될 때 종료 되며, iLbst와 $i_{L k}$ 의 수식은 다음과 같다.

$$
\begin{aligned}
& i_{L_{\text {bst }}}(t)=I_{1} \cos \omega_{\text {total }} t-\frac{\left(V_{\text {in }}+V_{C_{r}}\right)}{Z_{\text {tatal }}} \sin \omega_{\text {total }} t \\
& i_{L_{k}}(t)=I_{1} \cos \omega_{r} t-\frac{V_{C_{r}}}{Z_{r}} \sin \omega_{r} t
\end{aligned}
$$

모드 $3\left(t_{2} \sim t_{3}\right)$ :

음의 전류 $i S 2$ 는 역병렬 다이오드로 흐르게 되고, 이 때 $S 2$ 를 턴-오프 시켜 $\mathrm{ZVS}$ 조건을 만족 시킨다. 공진 회로의 전류는 최저까지 감소한 뒤 다시 증가한다. 이 모드는 Lbst의 자화 에너지가 감소하고 전류 형태로 방 출될 때 끝난다. $i_{L b s t}$ 와 $i_{L k}$ 의 수식은 다음과 같다.

$$
i_{L_{b s t}}(t)=I_{2} \cos \omega_{\text {total }} t+\frac{\left(V_{\text {in }}-V_{C_{r}}\right)}{Z_{\text {tatal }}} \sin \omega_{\text {total }} t
$$

$i_{L_{k}}(t)=I_{2} \cos \omega_{r} t+\frac{I_{M_{3}}-V_{C_{r}}}{Z_{r}} \sin \omega_{r} t$

모드 $4\left(t_{3} \sim t_{4}\right)$ :

$S_{2}$ 가 턴-오프 되었을 때, 변압기 코어에 자속이 형성 된다. $C_{r}$ 은 변압기의 전류에 의해 충전이 되며, 완전히 충전이 되었을 때 모드가 종료된다. 이 때, 전력은 배압 회로를 통하여 출력 단으로 전달된다. iLbst와 $i L k$ 의 수식 은 다음과 같다.

$$
\begin{aligned}
& i_{L_{b s t}}(t)=I_{3} \cos \omega_{\text {total }} t+\frac{\left(V_{\text {in }}-V_{C_{r}}\right)}{Z_{\text {tatal }}} \sin \omega_{\text {total }} t \\
& i_{L_{k}}(t)=I_{3} \cos \omega_{r} t+\frac{I_{M_{4}}-V_{C_{r}}}{Z_{r}} \sin \omega_{r} t
\end{aligned}
$$

모드 $5\left(t_{4} \sim t_{5}\right)$ :

$C_{r}$ 이 완전이 충전된 후, $i L k$ 는 $D_{2}$ 를 통하여 흐르게 되 고 출력 단으로 전력을 전달한다. iLbst는 선형적으로 감 소하고 변압기 2차 측에 유도된 전류 또한 천천히 감소 하게 된다. $S_{2}$ 가 턴-온 되면 이 모드는 종료된다. iLbst와 $i L k$ 의 수식은 다음과 같다.

$i_{L_{b s t}}(t)=I_{4} \cos \omega_{2} t-\frac{\left(V_{i n}+V_{C_{2}}\right)}{Z_{2}} \sin \omega_{2} t$

$i_{L_{k}}(t)=I_{4} \cos \omega_{r} t+\frac{I_{M_{5}}-V_{C_{2}}}{Z_{2}} \sin \omega_{r} t$

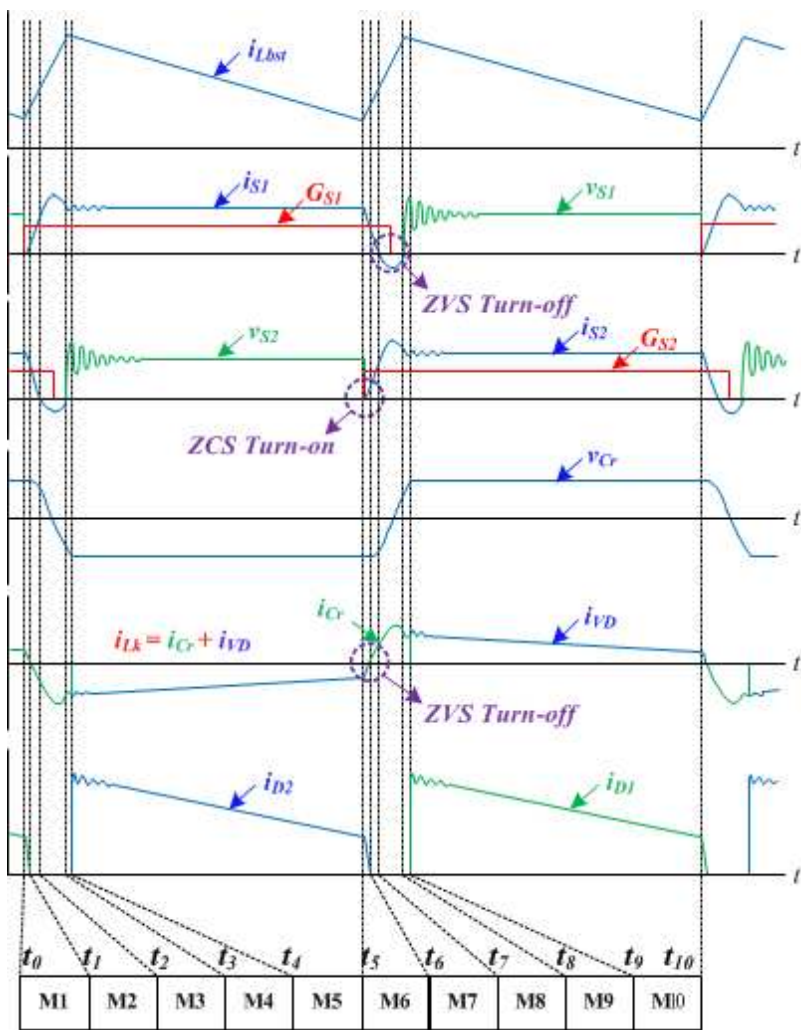

Fig. 3 Key waveforms of the proposed converter 

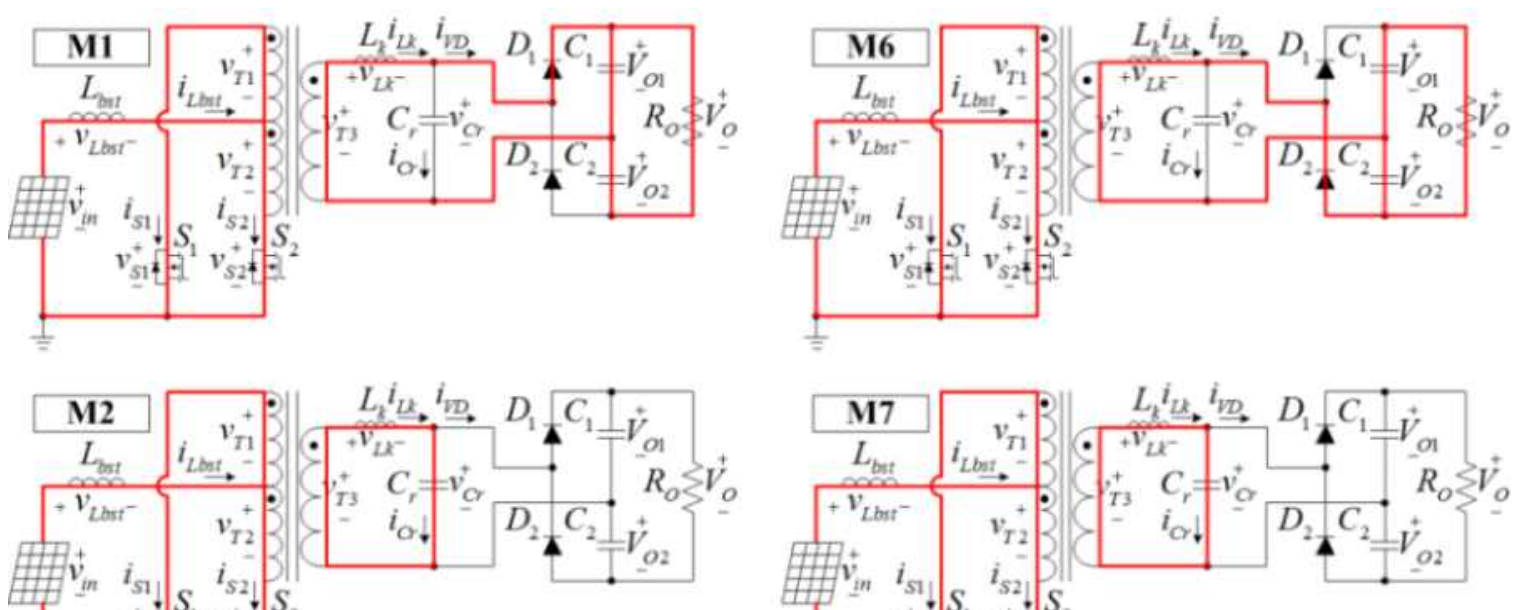

$v_{s 1}^{+}+S_{1}^{+} v_{s 2}^{+*}: S_{2}^{2}$
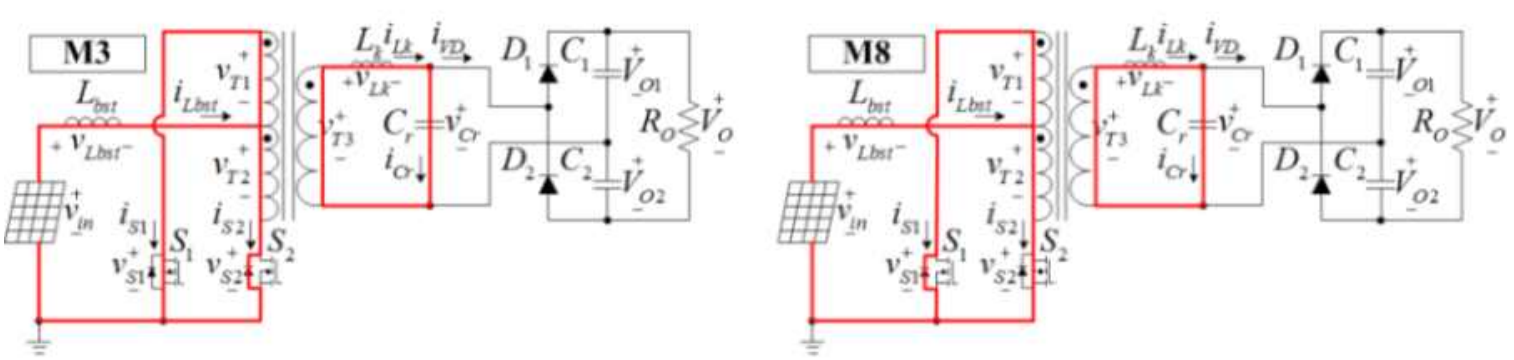

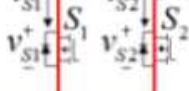
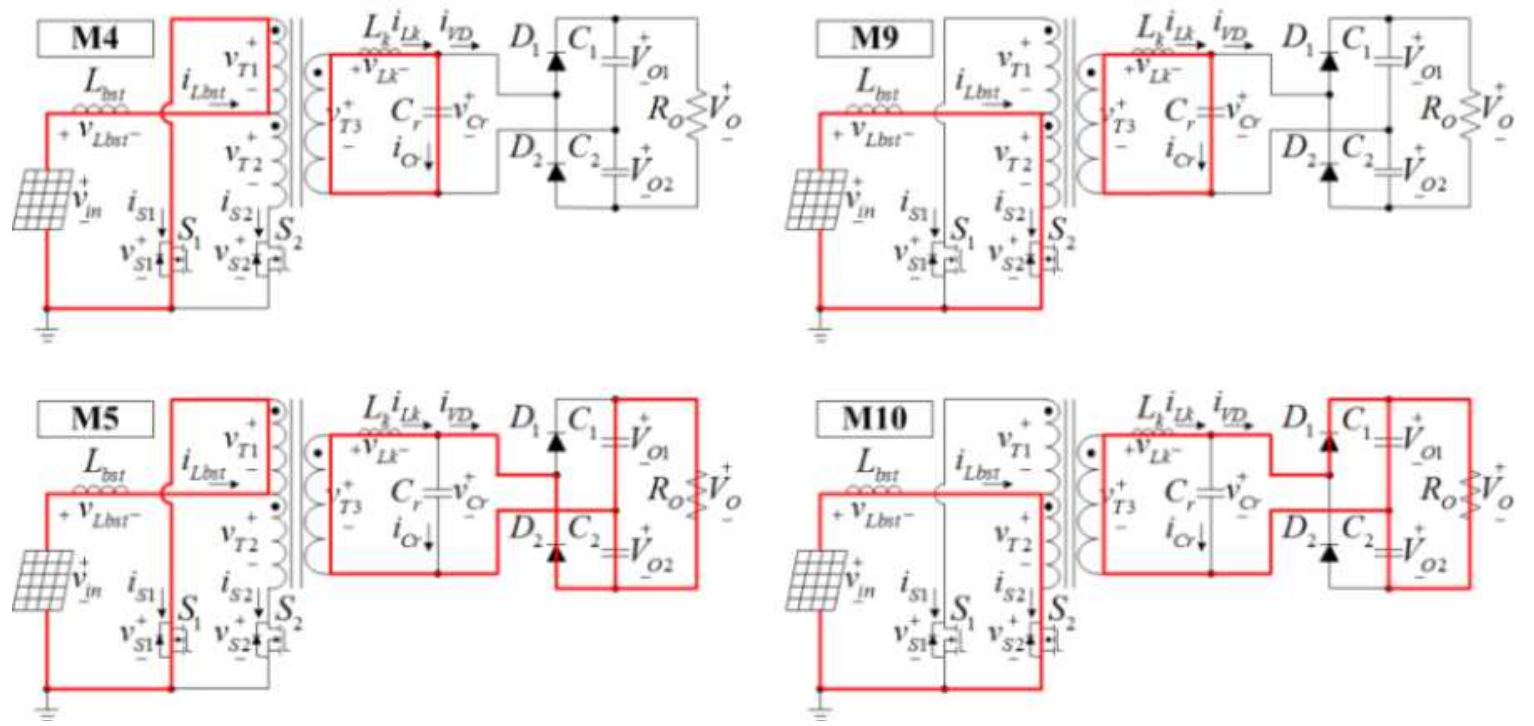

Fig. 4 Operation modes of the proposed converter with current flows

여기서,

$$
\begin{aligned}
& L_{b s t}+L_{k}=L_{\text {total }} \\
& \omega_{r}=\frac{1}{2 \pi \sqrt{L_{k} C_{r}}}, \omega_{1}=\frac{1}{\sqrt{L_{\text {total }} C_{1}}} \\
& \omega_{2}=\frac{1}{\sqrt{L_{\text {total }} C_{2}}}, \omega_{\text {total }}=\frac{1}{\sqrt{L_{\text {total }} C_{r}}}
\end{aligned}
$$

$$
\begin{aligned}
& Z_{r}=\sqrt{\frac{L_{k}}{C_{r}}}, Z_{1}=\sqrt{\frac{L_{\text {total }}}{C_{1}}} \\
& Z_{2}=\sqrt{\frac{L_{\text {total }}}{C_{2}}}, Z_{\text {total }}=\sqrt{\frac{L_{\text {total }}}{C_{r}}}
\end{aligned}
$$

모드 6 10에서, 컨버터는 같은 동작을 반대편 소자로 반복한다. 
Fig. 5는 Lbst의 voltage- ${ }^{-}$second balance 조건을 위한 전류 $i L b s t$, 전압 VLbst 파형이다. $G$ 는 다음과 같이 계산 되며, $v L k$ 의 전압은 매우 작아 없다고 가정하였다.

$$
\begin{aligned}
& V_{\text {in }} T_{1}=\left(\frac{V_{o}}{2 n}-V_{i n}\right) T_{2} \\
& V_{\text {in }}\left(T_{1}+T_{2}\right)=\frac{V_{o}}{2 n} T_{2} \\
& \frac{V_{\text {in }}}{2} T_{s w}=\frac{V_{o}}{2 n} T_{2} \\
& \frac{V_{o}}{V_{\text {in }}}=n \frac{T_{s w}}{T_{2}} \\
& =n \frac{2 T_{s w}}{T_{s w}-T_{r e s}} \\
& \therefore G_{v}=\frac{2 n}{1-\frac{f_{s w}}{f_{r e s}}}
\end{aligned}
$$

전압 전달비 $G$ 는 권선비 $n$ 에 비례하고, 공진주파수 fes 가 증가함에 따라 감소하며 스위칭 주파수 $f_{w w}$ 가 증가함 에 따라 증가한다.

입력 전압인 태양전지의 출력 전압 $\mathrm{V}_{j v}$ 에 따라 컨버터 의 출력 전압을 유지하기 위하여 $f_{S W}$ 가 가변되어야 한다.

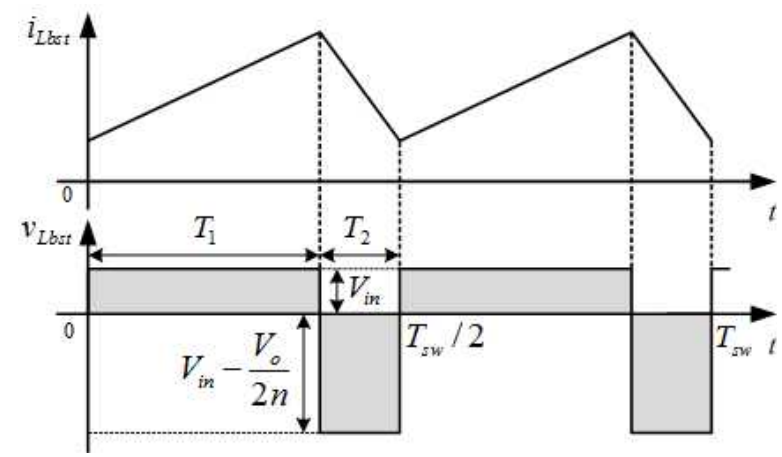

Fig. 5 Voltage- ${ }^{-}$second balance condition of $L_{b s t}$

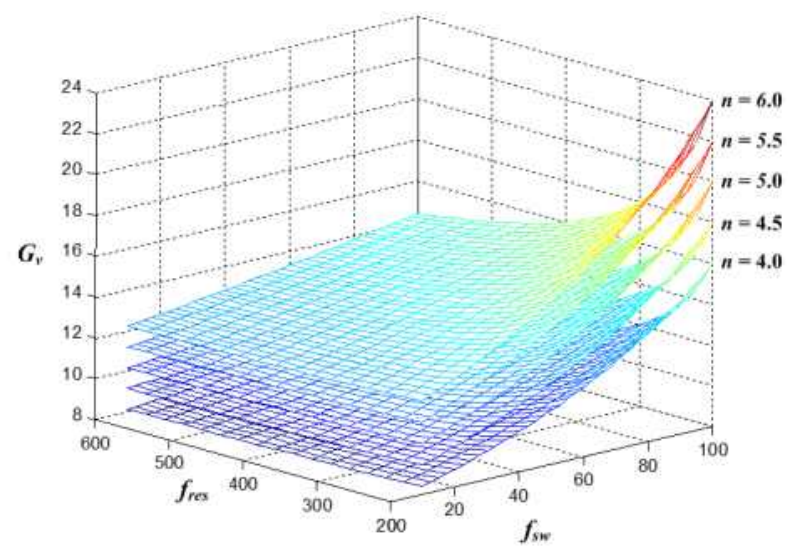

Fig. $6 G_{V}$ according to the $n$ and $f_{\text {res }}$
Fig. 6 는 변압기 권수비 $n$ 과 공진 주파수 fres에 따른 $\mathrm{Gv}$ 이다.

Fig. 7는 $n$ 에 따른 $G v$ 를 나타낸다. fres를 $400 \mathrm{kHz}$ 로 가 정하고 $n$ 을 4.0 에서 6.0 까지 증가시켰다. $n=5.5$ 가 $\mathrm{V} p \mathrm{v}$ $33.3 \mathrm{~V}$ 를 $V_{o} 400 \mathrm{~V}$ 로 승압하는데 적합한 $G v$ 를 갖는다.

Fig. 8은 fese에 따른 $G v$ 를 나타낸다. 이 단계에서는 $n=5.5$ 라 가정하고, fres를 $200 \mathrm{kHz}$ 에서 $600 \mathrm{kHz}$ 로 증가시켰 다. $f e s$ 가 낮을수록 높은 $G$ 를 갖지만, 큰 누설 인덕턴스 에서의 손실을 고려하여야 하고, 높을수록 낮은 $G_{V}$ 를 갖 게 되므로 충분한 $G$ 를 확보할 수 있는 $f e s=400 \mathrm{kHz}$ 로 결정하였다 ${ }^{[13]-[14]}$

\section{2 스위칭 구현}

소프트 스위칭과 일사량에 따른 MPPT를 위해서는 스위칭 주파수와 통류율이 함께 가변되어야 한다. 본 논 문에서는 $\mathrm{P} \& \mathrm{O}$ (Perturbation and Oscillation) MPPT를 사용하였다. PWM을 위한 레퍼런스 파형의 크기는 스위 칭 주기 $T_{S w}$ 와 공진 주기 $T_{r e s}$ 로부터 결정된다. 스위치의 턴-온 시간 $T_{o n}$ 은 $T_{s w}$ 의 $1 / 2$ 와 $T_{r e s}$ 의 $1 / 4$ 의 합이다. 이 수식은 식 (15)와 같다. $S_{l}$ 이 턴-온 되고나서 $(1 / 2) T_{S W}$ 후에 $S_{2}$ 가 턴-온 된다. 소프트 스위칭을 위해서 스위치

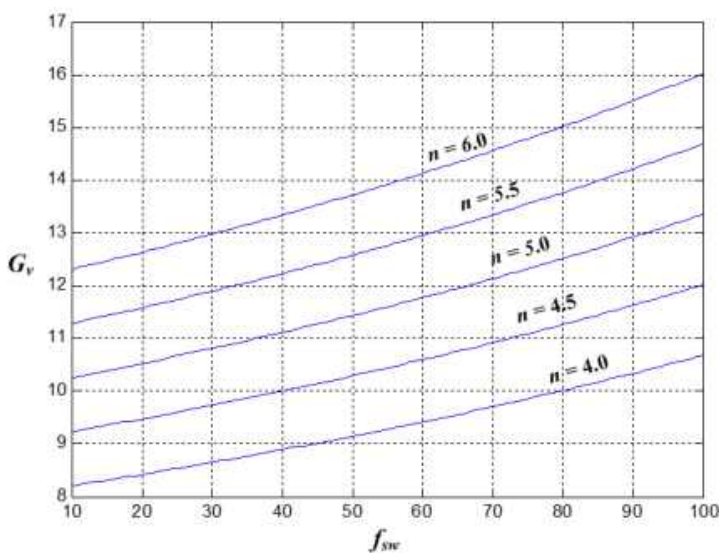

Fig. $7 G_{V}$ according to $n$

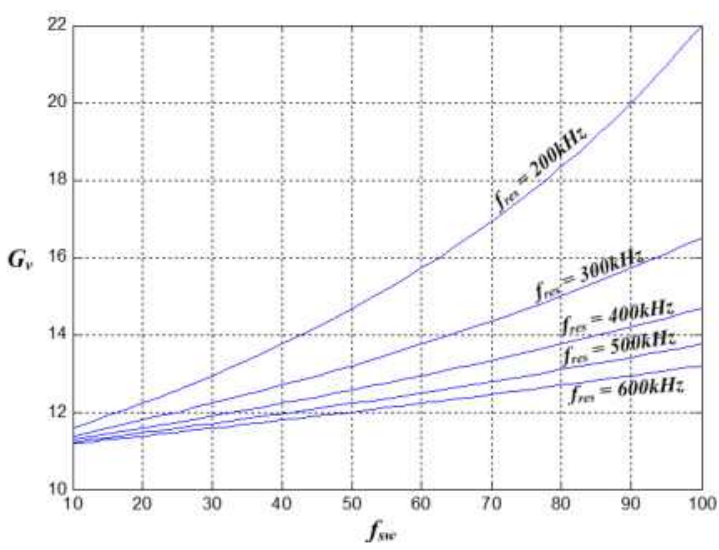

Fig. $8 G_{V}$ according to $f_{r e s}$ 
의 역병렬 다이오드가 도통 되는 순간 $\mathrm{ZVS}$ 조건에서 턴-오프 되어야 한다. 따라서, $S_{2}$ 가 턴-온 되고나서 (1/4) $T_{r e s}$ 후에, $S$ 은 ZVS 조건을 만족하는 턴-오프를 할 수 있다.

$$
T_{o n}=\frac{T_{s w}}{2}+\frac{T_{r e s}}{4}
$$

식 (15)를 스위칭 주파수 $T_{s w}$ 로 나누어 통류율 $D$ 를 계산하면 다음과 같다.

$$
D=\frac{1}{2}+\frac{T_{r e s}}{4 T_{s w}}
$$

DC-link를 갖는 two-stage 구조의 태양광 MIC에서, $\mathrm{DC}-\mathrm{DC}$ 컨버터는 MPPT를 수행하여야 한다. 그리고 $\mathrm{DC}-\mathrm{link}$ 전압과 계통 전류는 $\mathrm{DC}-\mathrm{AC}$ 인버터에서 제어 되어야 한다. 최대 전력을 출력하기 위하여, 태양전지 출력 전압인 컨버터 입력 전압 $V_{p v}$ 와 태양 전지 출력 전 류 $i_{p v}$ 를 제어하여야 하고, MPPT 기법에 따라 센서의 수를 줄일 수 있다. MPPT의 출력은 레퍼런스 스위칭 주기 $T_{S W}{ }^{*}$ 로 설정하였다. $\mathrm{PWM}$ 을 위한 레퍼런스의 크기 를 결정하는 연산은 레퍼런스 계산기(calculator)에서 계 산 되었다. 계산된 레퍼런스와 캐리어의 비교를 통하여 스위치의 게이트 시그널을 생성한다.

$\mathrm{DC}-\mathrm{AC}$ 인버터는 $\mathrm{AC}$ 계통에 연계되기 때문에, 계통 전압 Vgrid는 제어될 수 없기 때문에, 전력의 품질은 계 통 전류 $i_{\text {grid }}$ 에 따라 결정된다. 전압원 인버터에서 계통 전류 제어는 즉각적으로 전류 파형을 제어 할 수 있고 높은 정확도를 갖는다. 이 장점은 낮은 왜곡과 고조파 노이즈를 갖는 전류를 계통에 주입할 수 있다. Fig. 9은 태양광 $\mathrm{MIC}$ 의 전체 제어 블록도이다. 제안된 컨버터의 제어 블록도는 좌측에 나타나 있다.

\section{4. 시뮬레이션}

제안된 컨버터의 시뮬레이션 및 실험의 파라미터는 Table 1과 같다. 시뮬레이션은 PSIM 9.0을 사용하여 구 현하였다.

그림 10(a)는 PWM을 위한 캐리어와 레퍼런스의 파형 을 나타낸다. 그림 $10(\mathrm{~b})$ 는 $S_{I}$ 의 게이트 시그널 $G S I$, 전 류 $i S 1$, 전압 $V S I$ 의 파형이다. 그림 $10(\mathrm{c})$ 는 $S_{2}$ 의 게이트 시그널 $G S 2$, 전류 $i s 2$, 전압 $\mathrm{VS} 2$ 의 파형이다. 이 파형들로 부터 1차 측 스위치 $S_{1}, S_{2}$ 의 $\mathrm{ZCS}$ 조건에서의 턴-온과 ZVS 조건에서의 턴-오프를 각각 확인할 수 있다. 게이 트 시그널은 각 스위치의 전류가 역병렬 다이오드로 흐 를 때 턴-오프 시켜준다.

그림 11 은 스위치 $S_{1}$ 의 소프트 스위칭을 위한 턴-온 시간을 나타낸다. 공진 주파수에 의한 $(1 / 4) T_{r e s} \approx 600 \mathrm{~ns}$
Table 1 Parameters of the simulation and experiment

\begin{tabular}{l|c|c}
\hline \multicolumn{1}{c|}{ Parameter } & Value & Unit \\
\hline \hline Input Voltage $V_{p V}$ & $20 \sim 40$ & $\mathrm{~V}$ \\
\hline MPP Voltage $V_{m p p}$ & $22.7 \sim 33.3$ & $\mathrm{~V}$ \\
\hline Output Voltage $V_{o}$ & $350 \sim 400$ & $\mathrm{~V}$ \\
\hline Output Power $P_{o}$ & 250 & $\mathrm{~W}$ \\
\hline Magnetizing Inductance $L_{m}$ & 950 & $\mu \mathrm{H}$ \\
\hline $\begin{array}{l}\text { Secondary Leakage } \\
\text { Inductance } L_{k}\end{array}$ & 34 & $\mu \mathrm{H}$ \\
\hline Resonant Capacitor $C_{r}$ & 4.7 & $\mathrm{nF}$ \\
\hline Switching Frequency $f_{S W}$ & $30 \sim 80$ & $\mathrm{kHz}$ \\
\hline Transformer turn-ratio $n$ & 5.5 & \\
\hline \hline
\end{tabular}

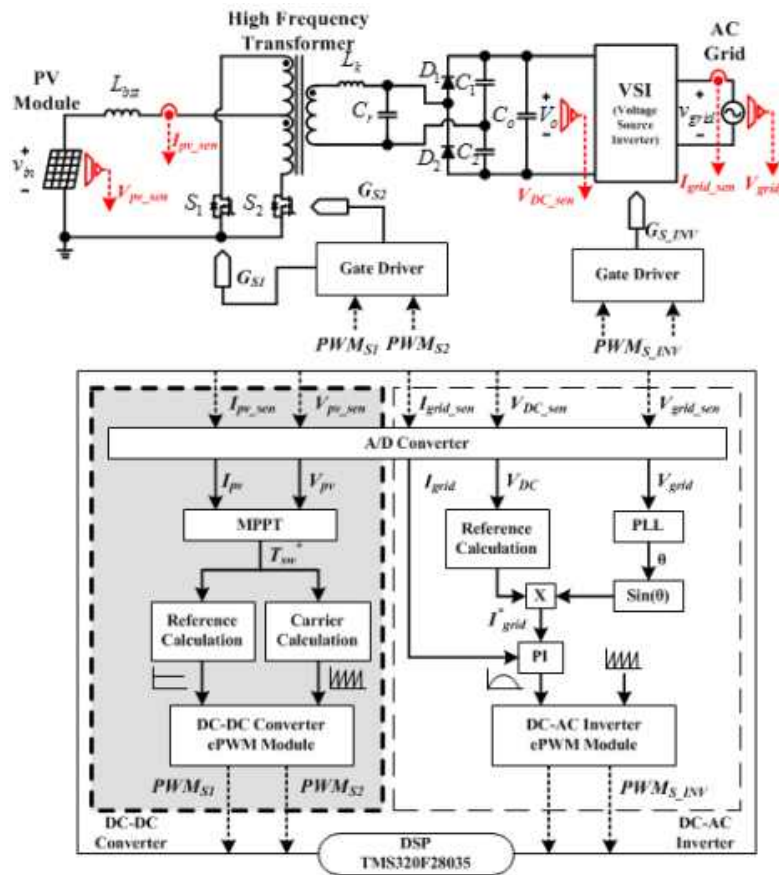

Fig. 9 Total control block diagram of PV-MIC
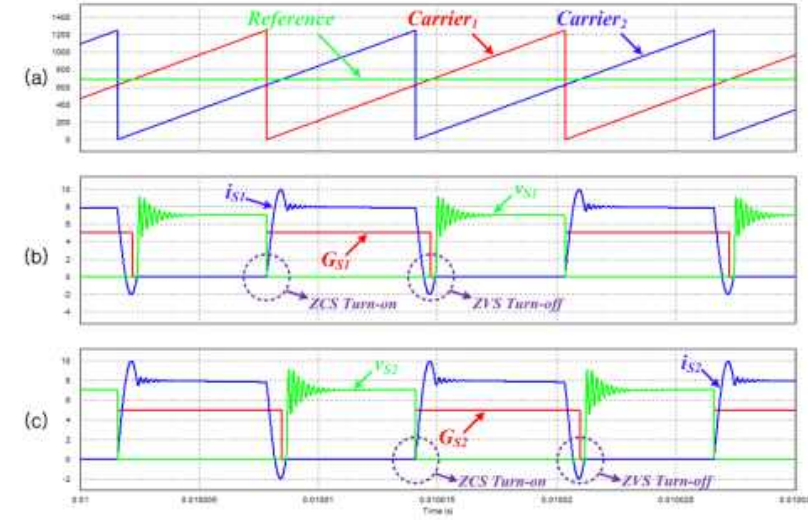

Fig. 10 (a) Carriers and a reference for PWM (b) Waveforms of primary switch $S_{1}$, (c) Waveforms of primary switch $S_{2}$ 


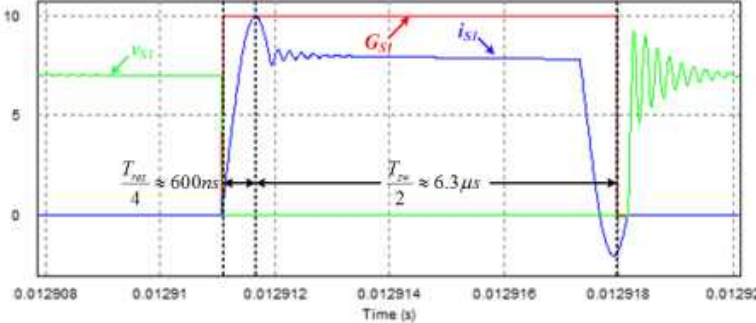

Fig. 11 Resonant and switching period of primary switch $S_{1}$

와 MPPT 수행에 의한 스위칭 주파수 약 $79 \mathrm{kHz}$ 에 해당 하는 $(1 / 2) T_{S w} \approx 6.3 \mu \mathrm{s}$ 를 확인하였다.

\section{5. 실험 결과}

본 논문에서 제안된 컨버터의 실험 결과는 $250 \mathrm{~W}$ 실 험 세트와 Agilent의 $\mathrm{E} 4350 \mathrm{~B}$ 태양광 어레이 시뮬레이터 를 이용하여 실험 하였다. Table 2는 LPC250SM 태양광 모듈의 출력에 따른 $\mathrm{SC}$ (short circuit) 전류, $\mathrm{MPP}$ 전류, $\mathrm{OC}$ (open circuit) 전류, MPP 전압을 나타내며 태양광 어레이 시뮬레이터로 모사하였다. Microcontroller는 Texas Instruments의 TMS320F28035를 사용하였고 DC-link의 초기 충전을 위하여 soft starting 기법을 사 용하였다.

Fig. 12는 Table 2에서 주어진 각 부하별 조건에 따른

Table 2 PV simulator parameter According to the Irradiation

\begin{tabular}{c|c|c|c|c}
\hline $\begin{array}{c}\mathrm{PV} \\
\text { Power }\end{array}$ & $\begin{array}{c}\text { SC } \\
\text { Current }\end{array}$ & $\begin{array}{c}\text { MPP } \\
\text { Current }\end{array}$ & $\begin{array}{c}\text { OC } \\
\text { Voltage }\end{array}$ & $\begin{array}{c}\text { MPP } \\
\text { Voltage }\end{array}$ \\
\hline \hline $25 \mathrm{~W}$ & $1.2 \mathrm{~A}$ & $1.1 \mathrm{~A}$ & $28 \mathrm{~V}$ & $22.7 \mathrm{~V}$ \\
\hline $50 \mathrm{~W}$ & $2.2 \mathrm{~A}$ & $2 \mathrm{~A}$ & $30.8 \mathrm{~V}$ & $25 \mathrm{~V}$ \\
\hline $75 \mathrm{~W}$ & $3 \mathrm{~A}$ & $2.8 \mathrm{~A}$ & $33 \mathrm{~V}$ & $26.8 \mathrm{~V}$ \\
\hline $125 \mathrm{~W}$ & $4.7 \mathrm{~A}$ & $4.4 \mathrm{~A}$ & $35 \mathrm{~V}$ & $28.4 \mathrm{~V}$ \\
\hline $187.5 \mathrm{~W}$ & $6.7 \mathrm{~A}$ & $6.3 \mathrm{~A}$ & $36.5 \mathrm{~V}$ & $29.7 \mathrm{~V}$ \\
\hline $250 \mathrm{~W}$ & $7.5 \mathrm{~A}$ & $7.5 \mathrm{~A}$ & $39 \mathrm{~V}$ & $33.3 \mathrm{~V}$ \\
\hline \hline
\end{tabular}

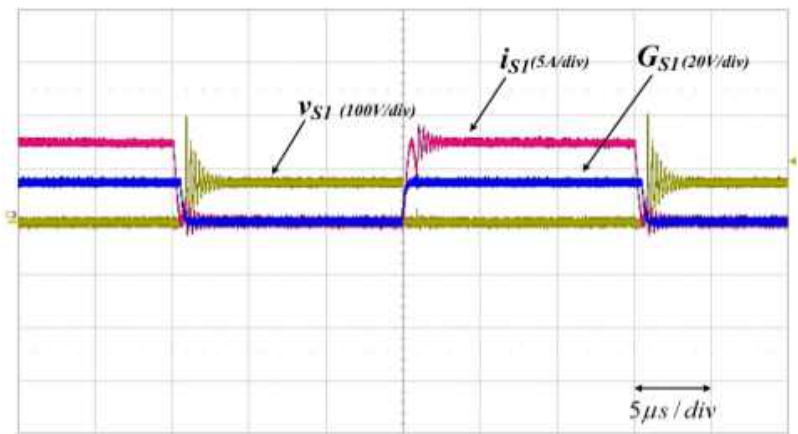

(a)
$S_{1}$ 의 전압, 전류, 게이트 시그널 실험 파형이다. 모든 부 하 조건에서 ZCS 턴-온 및 ZVS 턴-오프를 확인할 수 있다. 게이트 시그널은 각 스위치의 전류가 역병렬 다이 오드로 흐를 때 턴-오프 시켜준다. Fig. 13은 $S_{1}$ 의 ZCS 턴-온 및 ZVS 턴-오프 시의 확대된 파형이다. (1/4) Tres

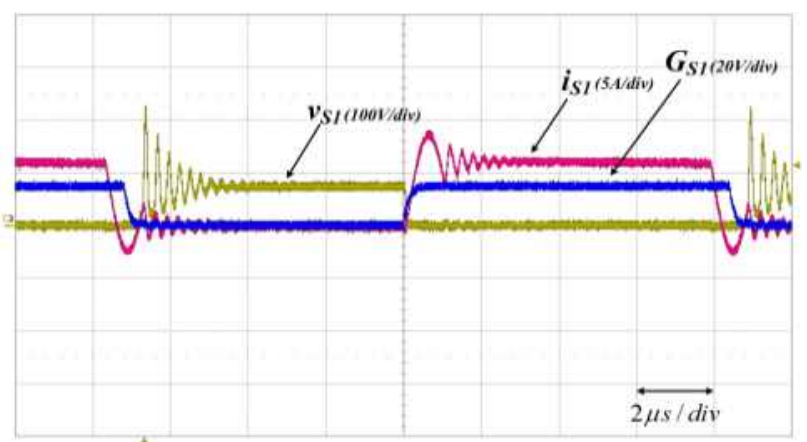

(b)

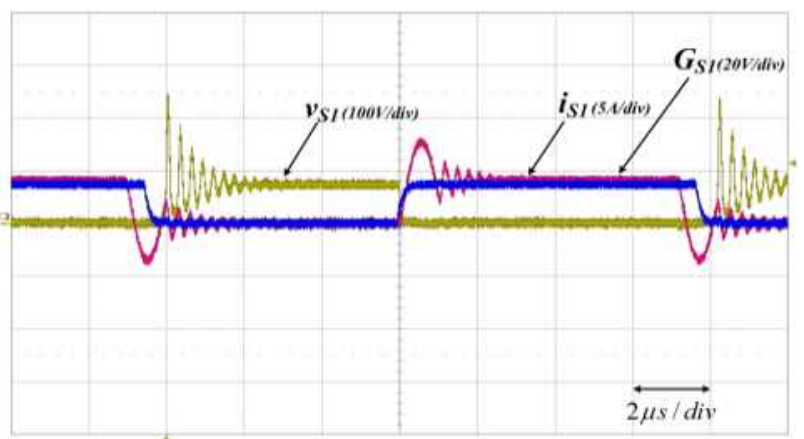

(c)

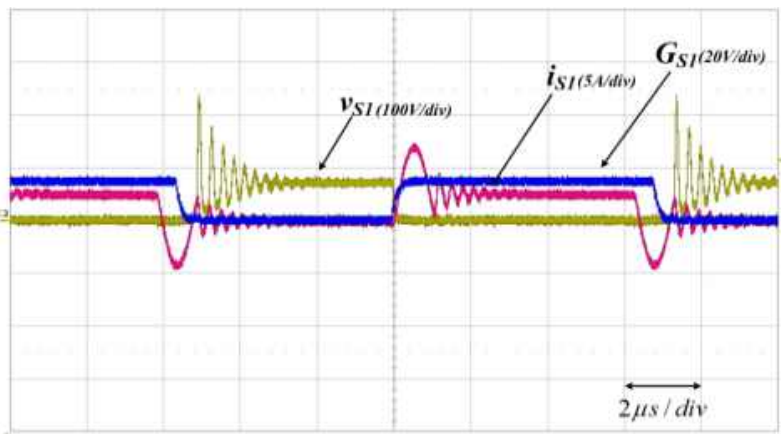

(d)

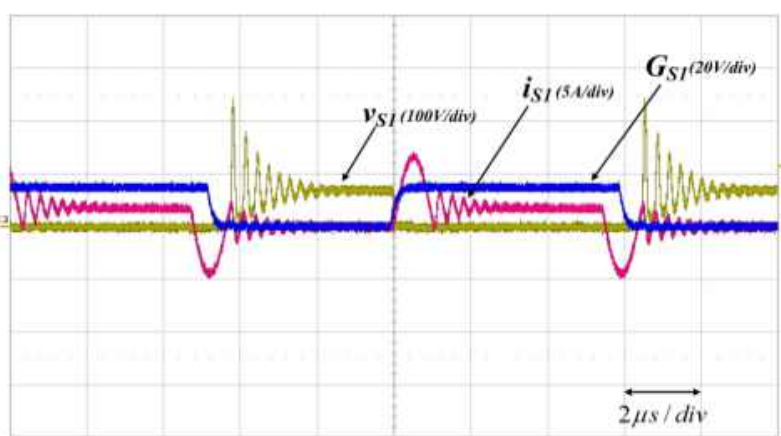

(e)

Fig. 12 Voltage, current and gate signal of $S_{1}$ according to the load conditions (a) 100\%(250W), (b) $75 \%(187.5 \mathrm{~W})$, (c) $50 \%(125 \mathrm{~W}),(d) 30 \%(75 \mathrm{~W}),(e) 50 \%(50 \mathrm{~W})$ 


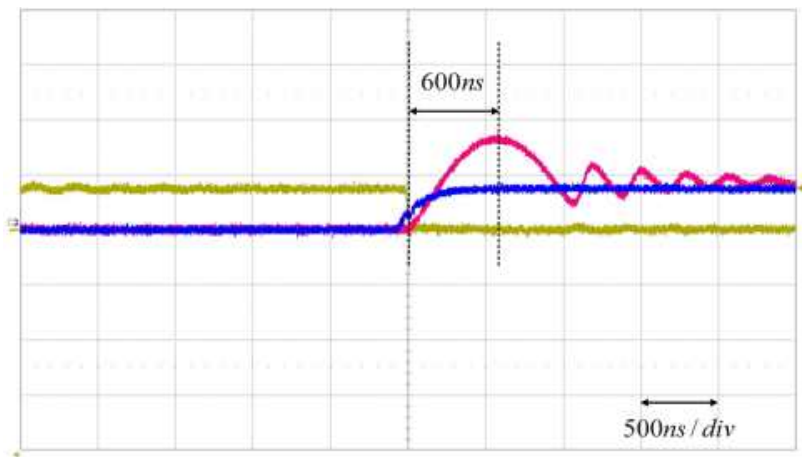

(a)

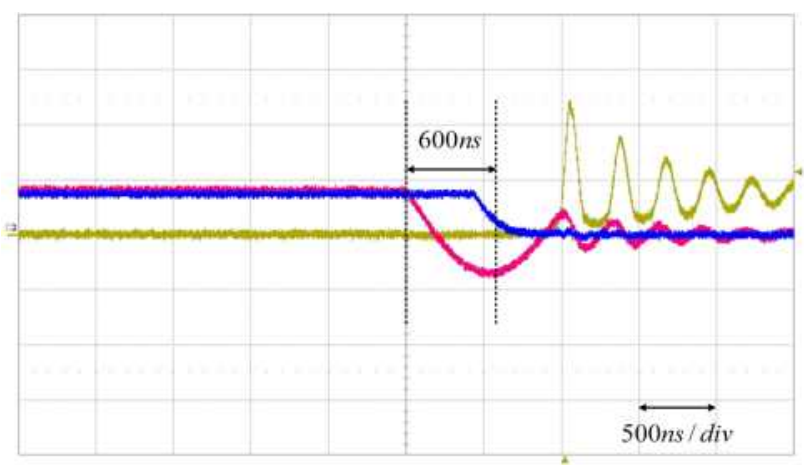

(b)

Fig. 13 (a) ZCS turn-on, (b) ZVS turn-off

의 시간인 $600 \mathrm{~ns}$ 를 확인할 수 있고, 그 시점에서 게이트 시그널이 오프 되는 것을 확인 하였다.

\section{6. 결 론}

본 논문에서 $\mathrm{AC}$ 모듈형 태양광 모듈 집적형 컨버터 를 위한 소프트 스위칭 $\mathrm{DC}-\mathrm{DC}$ 컨버터를 제안하였다. $\mathrm{DC}-\mathrm{DC}$ 컨버터의 토폴로지는 $\mathrm{LC}$ 병렬 공진을 이용한 전류원형 푸쉬-풀 컨버터이다. 고주파 변압기, 부스트 인덕터, 배압 회로를 통한 승압으로 계통연계에 필요한 $350 \mathrm{~V}$ 이상의 $\mathrm{DC}$ 전압으로 고승압을 하였다. 변압기 1 차 측 스위치에서 ZVS 턴-오프와 ZCS 턴-온을 확인하 였다. 각 스위치에서 스위칭 손실을 줄이기 위한 소프트 스위칭은 태양광 모듈의 최대 전력점 추종을 통하여 수 행하였다. 각 부 파형과 최대 전력점 추종은 시뮬레이션 과 $250 \mathrm{~W}$ 실험 세트를 통하여 확인되었고, 최대 효율은 $96.6 \%$ 이다.

이 논문은 2012년도 성균관대학교 학술연구비 지원에 의하여 연구되었음

\section{References}

[1] Quan Li, Peter Wolfs, "A Review of the Single Phase Photovoltaic Module Integrated Converter Topologies With Three Different DC link Configurations," Power Electronics, IEEE Transactions on, Vol. 23, No. 3, pp. 1320-1333, May 2008.

[2] Singh, B., Vyas, A.L., Chandra, A., Kamal-Al-Haddad, "Analysis and design of isolated solar-PV energy generating system," Industry Applications Society Annual Meeting (IAS), pp. 1-6, 2011.

[3] D. C. Martins, R. Demonti, A. S. Andrade, O. H. Gonalves, "Analysis of Utility Interactive Photovoltaic Generation System using a Single Power Static Inverter," Asian J. Energy Environment, Vol. 5, No. 2, pp. 115-137, 2004.

[4] Young Jin Lee, "Design and Efficiency Improvement of Power Conditioning System for Fuel Cell," 2010.

[5] Ivo Barbi, Roger Gules, "Isolated DC-DC Converters With High-Output Voltage for TWTA Telecommunication Satellite Applications," Power Electronics, IEEE Transactions on, Vol. 18, No. 4, pp. 975-984, July 2003.

[6] Chan Ki Park, "Power Conversion System for $1 \mathrm{~kW}$ Residential Fuel Cell Generation," 2007.

[7] Ryan, M.J., Brumsickle, W.E., Divan, D.M., Lorenz, R.D., "A new ZVS LCL-resonant push-pull DC-DC converter topology," Industry Applications Conference(IAS), Vol. 2, pp. 1673-1680, 1997.

[8] Chu C.-L., Li C.-H., "Analysis and design of a current-fed zero-voltage-switching and zero-currentswitching CL-resonant push-pull dc-dc converter," Power Electronics, IET, Vol. 2, pp. 456-465, 2009.

[9] Nome F.J., Barbi I., "A ZVS clamping modecurrent-fed push-pull DC-DC converter," Industrial Electronics, ISIE '98, IEEE International Symposium on, Vol. 2, pp. 617-621, July 1998.

[10] De Aragao Filho, W.C.P., Barbi I., "A Comparison Between Two Current- Fed Push-Pull DC-DC Converter-Analysis Design and Experimentation," Telecommunications Energy Conference, INTELEC '96, pp. 313-320, 1996.

[11] E.-H. Kim B.-H. Kwon, "High step-up resonant push-pull converter with high efficiency," Power Electronics, IET, Vol. 2, pp. 79-89, 2009.

[12] Lucas V. Hartmann, Maur'icio B. R. Correa and Antonio M. N. Lima, "A simple and effective control strategy for improved operation of a current-fed push-pull converter," Energy Conversion Congress and Exposition, IEEE, pp. 1098-1103, Sept. 2010.

[13] Rabello A.L., Marcio C.A., Sousa G.C.D., Vieira J.L.F., "A Fully Protected Push-Pull Current-Fed DC-DC Converter," Industrial Electronics, Control and Instrumentation, IECON 97, Vol. 2, pp. 587-592, 1997. 
[14] Domingo A. Ruiz-Caballero, Ivo Barbi, "A new flyback-current-fed push-pull DC-DC converter," Power Electronics, IEEE Transactions on, Vol. 14, pp. 1056-1064, Nov. 1999.

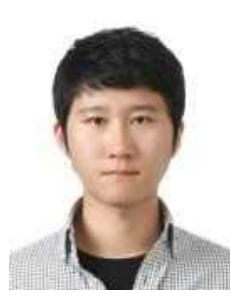

윤선 재 (尹善載)

1986년 8월 8일생. 2011년 2월 성균관대 전 자전기공학과 졸업. 2013년 동 대학원 이동 통신전력전자공학과 졸업(석사). 2013년 현 재 삼성전기 연구원.

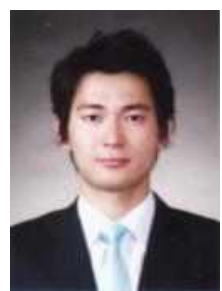

김영호(金榮浩)

1981년 9월 29일생. 2008년 2월 안양대 전 자전기공학과 졸업. 2010년 성균관대 대학 원 태양광시스템협동과정 졸업(석사). 2010 년 현재 동 대학원 태양광시스템협동과정 박사과정.

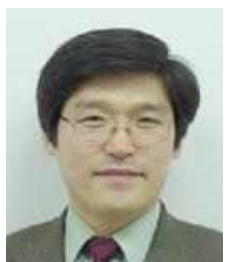

\section{정용채 (鄭龍采)}

1966년 2월 28일생. 1989년 한양대 전자공 학과 졸업. 1991년 한국과학기술원 전기 및 전자공학과 졸업(석사). 1995년 한국과학기 술원 전기 및 전자공학과 졸업(공박). 1995 년 1999년 LG전자 홈어플라이언스 연구소 선임연구원. 1999년 현재 남서울대 전자공학과 교수. 당 학회 편집이사.

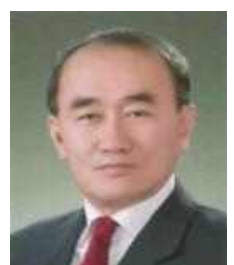

\section{원 충 연 (元忠淵)}

1955년 5월 10일생. 1978년 성균관대 공대 전기공학과 졸업. 1980년 서울대 공대 대학 원 전기공학과 졸업(공박). 1991년 12월 1992년 12월 미국 테네시 주립대학 전기공 학과 방문 교수. 1998년 현재 한국철도기 술연구원 심사위원. 2006년 현재 한국전력공사 PQ심사위원. 2006년 현재 차세대 첨단도시철도시스템(한국건설교통기술평 가원) 기술개발사업 운영위원. 2006년 현재 (주)로템 기술자문 위원. 2007년 현재 도시철도기술실무위원회 위원(건설교통부). 2007년 현재 삼성전기 에너지파워 연구 센터장. 2007년 2008 년 당 학회 부회장. 2010년 당 학회 회장. 현재 성균관대 정보 통신공학부 교수. 